\title{
Effect of the size of the deletion and clinical manifestation in Wolf-Hirschhorn syndrome: analysis of 13 patients with a de novo deletion
}

\author{
Dagmar Wieczorek ${ }^{1}$, Mario Krause ${ }^{2}$, Frank Majewski ${ }^{3}$, Beate Albrecht ${ }^{1}$, Denise Horn ${ }^{4}$, \\ Olaf Riess ${ }^{2,5}$ and Gabriele Gillessen-Kaesbach ${ }^{1}$
}

\footnotetext{
${ }^{1}$ Institut für Humangenetik, Universitätsklinikum, Essen; ${ }^{2}$ Molekulare Humangenetik, Ruhr-Universität, Bochum; ${ }^{3}$ Institut für Humangenetik und Anthropologie, Heinrich-Heine-Universität, Düsseldorf; ${ }^{4}$ Institut für Humangenetik, Virchow-Klinikum, Berlin; ${ }^{5}$ Abteilung für Medizinische Genetik, Universität Rostock, Germany
}

We performed clinical, cytogenetic, and molecular analyses on 13 patients ( 8 females and 5 males, aged 6 months to 13 years) with Wolf-Hirschhorn syndrome due to de novo deletions of chromosome 4p. All patients presented with the typical facial gestalt, microcephaly, and profound mental retardation. Other clinical signs were low birth weight $(10 / 13 ; 77 \%)$, postnatal short stature $(8 / 12 ; 66 \%)$, muscular hypotonia $(12 / 13 ; 92 \%)$, seizures $(11 / 13 ; 85 \%)$, congenital heart defects $(4 / 13 ; 31 \%)$, colobomata of iris $(4 / 12$; $33 \%)$, genital anomalies $(4 / 13 ; 31 \%)$, deafness $(3 / 13 ; 23 \%)$, and renal anomalies $(3 / 13 ; 23 \%)$. The smallest deletion was a submicroscopic terminal deletion of nearly $2.5 \mathrm{Mb}$. The largest was a terminal deletion of nearly $30 \mathrm{Mb}$. Cleft lip/palate, preauricular pits/tags, and congenital heart defects were present only in patients with terminal deletions larger than $10 \mathrm{Mb}$. The deviations from mean birth weight, birth length, and postnatal head circumference correlated with the size of the deletion. Determining the parental origin of the deletion with microsatellite markers, the maternal allele was missing in three patients and the paternal allele in eight patients. Our observations support the existence of a partial genotype-phenotype correlation in Wolf-Hirschhorn syndrome. European Journal of Human Genetics (2000) 8, 519-526.

Keywords: Wolf-Hirschhorn syndrome; deletion size; clinical manifestation; de novo deletion; parental origin of deletion

\section{Introduction}

Wolf-Hirschhorn syndrome (WHS) was first and independently published in 1965 by Wolf et al $^{1}$ and Hirschhorn et $\mathrm{al}^{2}$ and describes a wide spectrum of clinical signs in patients with terminal $4 p$ deletions. ${ }^{3-5}$ The minimal critical region has been narrowed down to $165 \mathrm{~kb}$ in the chromosomal band 4p16.3. ${ }^{6}$ Potential candidate genes such as WHSC 1 , WHSC2, and LETM 1 have been identified. ${ }^{7-9}$ Although multiorganic expression corresponds well with affected

Correspondence: Dagmar Wieczorek MD, Institut für Humangenetik, Universitätsklinikum Essen, Hufelandstr. 55, 45122 Essen, Germany. Tel.: +49 201 7234567; Fax: +49 2017235900 ; E-mail:

dagmar.wieczorek@uni-essen.de

Received 16 December 1999; revised 28 March 2000; accepted

28 March 2000 organs in WHS, a direct link between these candidate genes and the broad clinical spectrum is missing.

Different mechanisms causing WHS have been observed: de novo deletions, familial translocations, and de novo translocations. ${ }^{3,10}$ The rate of familial translocations in WHS patients has been reported to be up to $15 \%,{ }^{10} 66 \%$ of them maternally in herited. ${ }^{11}$ De novo events are estimated to occur in $85-87 \%$ of WHS patients ${ }^{10}$ and here the paternally derived deletions are more frequent. ${ }^{12,13}$

Here, we evaluate 13 WHS patients with de novo deletions by clinical, cytogenetic, and molecular analyses to assess the severity of the clinical phenotype in context of the size and origin of the deletion.

However, it is still an open debate as to whether the size of the deletion in WHS patients influences the clinical phenotype. ${ }^{14}$ The aim of this study was to assess the influence of the 
size of the deletion on the clinical phenotype in the context of previously published reports.

\section{Subjects and methods \\ Ascertainment}

Since 1996, we performed clinical, cytogenetic, molecular, and molecular-cytogen etic investigations in 22 patients with Wolf-Hirschhorn syndrome. De novo deletions have been observed in 13 of the patients described here. Another nine patients had familial $(3 / 22)$ or de novo translocations $(6 / 22)$ resulting in Wolf-Hirschhorn syndrome. They are described elsewhere. $^{15}$

\section{Clinical data}

Thirteen patients, eight female and five male, aged 6 months to 13 years, were investigated (Table1). Birth occurred usually at term, after 35 to 42 gestational weeks (mean 39 weeks). Mean birth weight was $2241 \mathrm{~g}$ (2.6 SD below mean). Mean birth length was $46.7 \mathrm{~cm}$ (1.8SD below mean), and mean

Table 1 Clinical findings in 13 WHS patients with de novo deletions

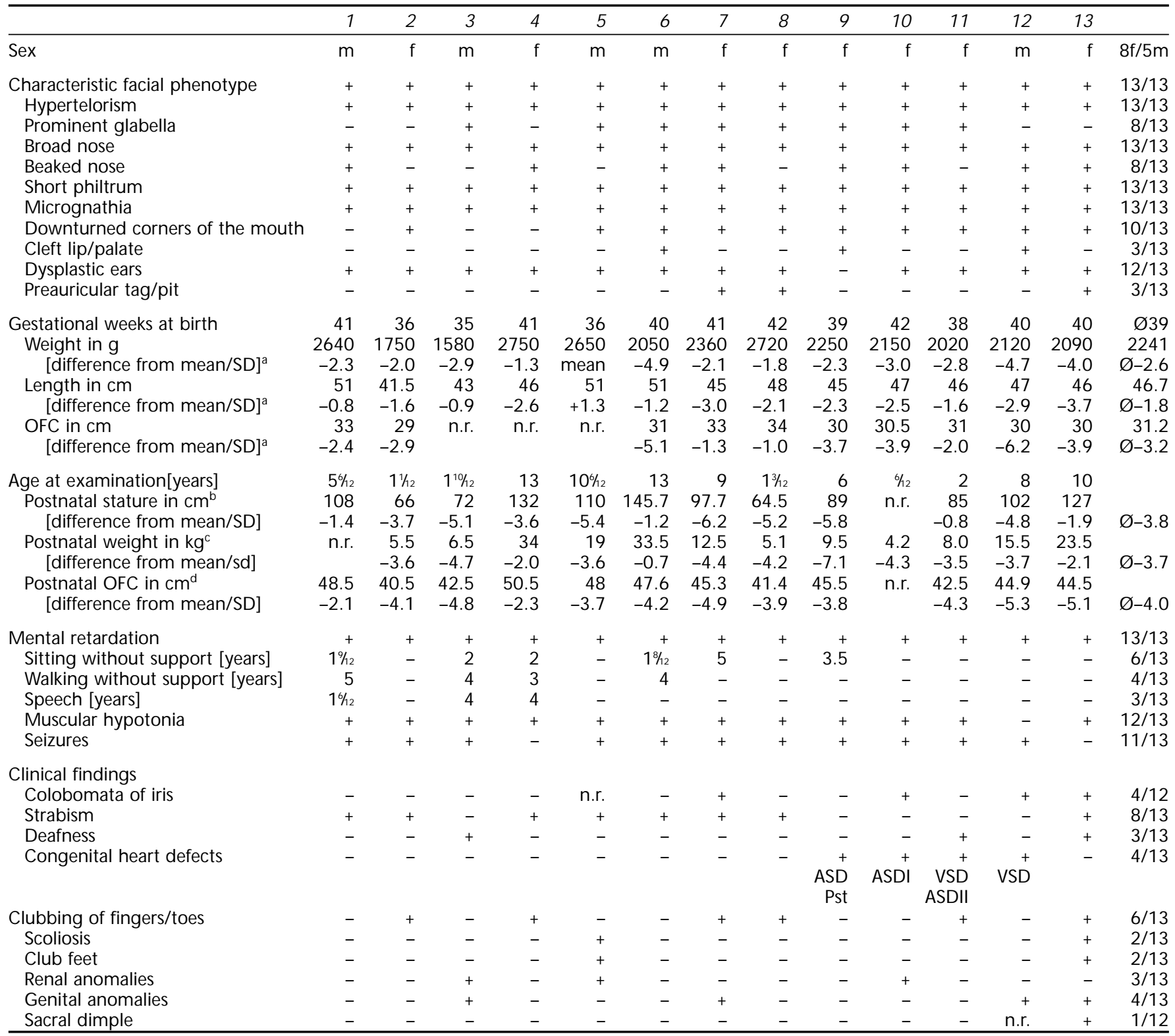

n.r.: not reported; f: female; m: male; $\varnothing$ : average; ASD: atrial septal defect; VSD: ventricular septal defect; Pst: pulmonic stenosis; ${ }^{a}$ according to Keen \& Pearse; 49 baccording to van Wieringen; 50 caccording to Kunze; ${ }^{51}$ daccording to Nellhaus. ${ }^{52}$ 
head circumference at birth was $31.2 \mathrm{~cm}$ (3.2 SD below mean). Diagnosis was suggested in these patients because of the typical facial formation comprising hypertelorism, strabism, prominent glabella, broad nose with flat tip, short philtrum, downturned corners of the mouth, cleft lip/palate, micrognathia, dysplastic ears, and preauricular pits/tags. The facial phenotypes of the patients are illustrated in Figurel. All patients were mentally retarded. Formal IQ testing has not been done. Other common clinical findings in WHS were muscular hypotonia (12/13), seizures (11/13), strabism $(8 / 13)$, clubbing of fingers/toes $(6 / 13)$, congenital heart defect (4/13) including ASD, VSD, and pulmonic stenosis, and genital anomalies (4/13) such as crypto-orchidism and hypertrophy of the clitoris, as well as colobomata of the iris $(4 / 12)$, deafness $(3 / 13)$, renal anomalies $(3 / 13)$ such as ureter duplex, unilateral renal agenesis, and vesico-ureteral reflux, scoliosis (2/13), club foot (2/13), and sacral dimple (1/12) (Table1).

\section{Cytogenetic investigations}

Chromosome studies including GTG-banding were performed on peripheral blood lymphocytes according to slightly modified standard techniques ${ }^{16}$ in all patients and their parents. The karyotypes of patients 1-13 are listed in Table2.

In patients1-4 the deletion is submicroscopic and is not visible at a banding resolution of 400 bands per haploid genome. Further molecular cytogenetic investigations were necessary to confirm the diagnosis. The remainder of the deletions range from $4 p 16.2$ to $4 p 15.2 .{ }^{17}$ The chromosomes of all parents showed a normal karyotype $(46, X X$ or $46, X Y)$.

\section{Fluorescence in situ hybridisation (FISH)}

DNA from cosmids pC847.351 (D4F26), ${ }^{18}$ CD2 (D4S90), ${ }^{19}$ 33c6 (D4S43), ${ }^{20}$ L21f12 (D4S180), L228a7 (D4S81), ${ }^{21}$ L247f6 containing the FGFR3 gene, ${ }^{22}$ and inter-Alu PCR products ${ }^{23}$ from YAC 877G6, 405D10, 794D12, 225D2, 435A11, 400F9, 848G12, and 796D3 (CEPH) were labelled with digoxigenin by using a BRL nick-translation kit (Gibco, Life Technologies, Gaitherburg, MD, USA). Labelled cosmid and YAC DNA was separated from unincorporated nucleotides by using $1800 \mathrm{ml}$ Centricon 30filters (Amicon, Beverly, MA, USA). FISH was performed as described by Lichter et al. ${ }^{24}$ Labelled cosmid DNA (50ng) or YAC DNA (100 ng) was mixed with human Cot-1 fraction DNA to suppress repetitive sequences or block a

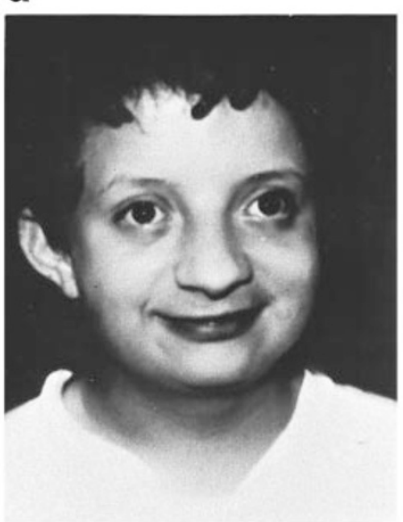

e

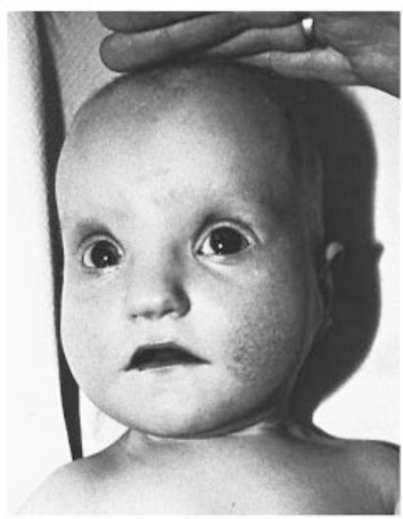

b

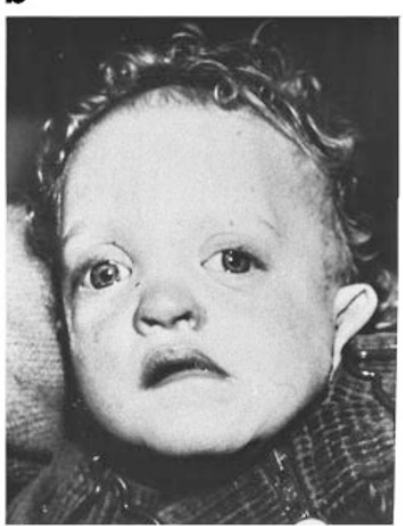

f

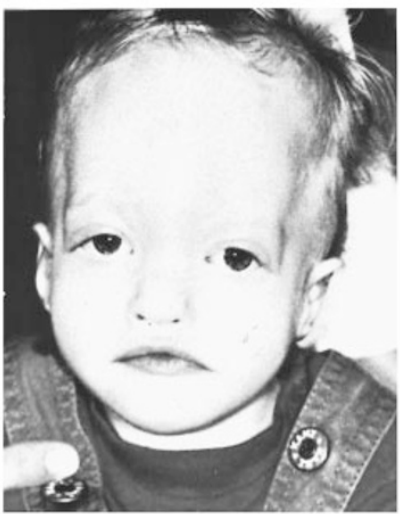

C

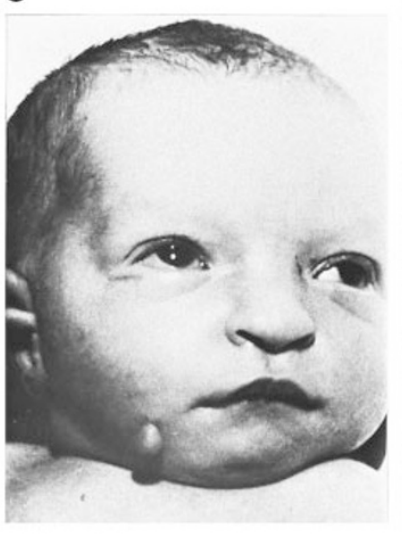

g

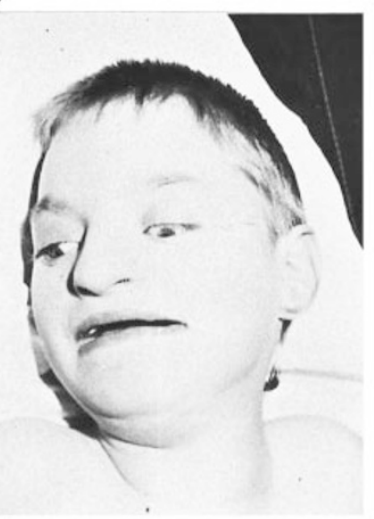

d

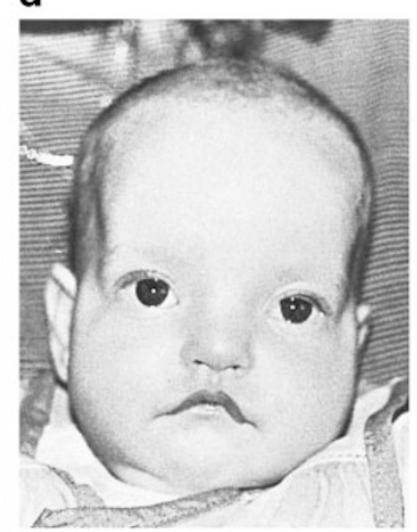

h

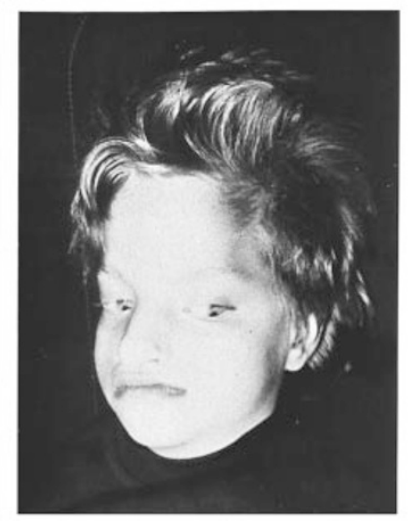

Figure 1 Facial features of 8 patients with WHS. a Patient 4, b Patient 6, c Patient 7, d Patient 9, e Patient 10, f Patient 11 , g Patient 12, h Patient 13. 
Table 2 Cytogenetic and molecular results in 13 WHS patients with de novo deletions

\begin{tabular}{|c|c|c|c|c|c|c|c|c|c|c|c|c|c|c|c|c|}
\hline $\begin{array}{l}\text { Distance } \\
\text { from } 4 \text { pter }\end{array}$ & $\begin{array}{l}\text { Mikrosatellite } \\
\text { marker }\end{array}$ & Cosmid & YAC & $\begin{array}{l}1 \\
46, X Y\end{array}$ & $\begin{array}{l}2 \\
46, x X\end{array}$ & $\begin{array}{l}3 \\
46, X Y\end{array}$ & $\begin{array}{l}4 \\
46, X X\end{array}$ & $\begin{array}{l}5 \\
46, X Y \\
\operatorname{del}(4) \\
(p 16.2)\end{array}$ & $\begin{array}{l}6 \\
46, X Y, \\
\text { del(4) } \\
\text { (p16.2) }\end{array}$ & $\begin{array}{l}7 \\
46, X X \\
\text { del(4) } \\
(p 16.2)\end{array}$ & $\begin{array}{l}8 \\
46, X X \\
\text { del }(4) \\
(p 16.1)\end{array}$ & $\begin{array}{l}9 \\
46, X X \\
\text { del(4) } \\
(p 15.3)\end{array}$ & $\begin{array}{l}10 \\
46, X X \\
\text { del(4) } \\
\text { (p15.3) }\end{array}$ & $\begin{array}{l}11 \\
46, X X \\
\operatorname{del}(4) \\
(p 15.3)\end{array}$ & $\begin{array}{l}12 \\
46, X Y \\
\operatorname{del}(4) \\
(p 15.2)\end{array}$ & $\begin{array}{l}13 \\
46, X X \\
\text { del(4) } \\
\text { (p15.2) }\end{array}$ \\
\hline$-200 \mathrm{~kb}$ & & $\begin{array}{l}\text { pC847.351 } \\
\text { (D4F26) }\end{array}$ & & del & del & del & del & del & del & del & del & del & del & del & del & del \\
\hline$-300 \mathrm{~kb}$ & & $\begin{array}{l}\text { CD2 } \\
\text { (D4S90) }\end{array}$ & & del & del & del & & & & & & & & & & \\
\hline$-1.2 \mathrm{Mb}$ & & $\begin{array}{l}\text { pC678 } \\
\text { (D4S96) }\end{array}$ & & del & del & del & del & del & del & del & del & del & del & del & del & del \\
\hline$-1.8 \mathrm{Mb}$ & & $\begin{array}{l}\text { pC385.12 } \\
\text { (D4S98) }\end{array}$ & & del & del & del & & & & & & & & del & & \\
\hline$-1.9 \mathrm{Mb}$ & L75B9 Rep. & & & $M$ & $P$ & & $P$ & & & $P$ & & n.i. & $P$ & $P$ & $M$ & $P$ \\
\hline$-2.0 \mathrm{Mb}$ & D4S1182 & & & n.i. & n.i. & & n.i. & & & $P$ & & $\mathrm{P}$ & n.i. & n.i & $M$ & n.i. \\
\hline$-2.2 \mathrm{Mb}$ & D4S43 & $\begin{array}{l}33 c 6 \\
\text { (D4S43) }\end{array}$ & & del & del & $P$ & n.i. & $M$ & & $P$ & & n.i. & & $P$ & $M$ & $P$ \\
\hline$-2.8 \mathrm{Mb}$ & & $\begin{array}{l}24716 \\
\text { (D4S182) }\end{array}$ & & n.d. & n.d. & del & del & & & & & del & & & & \\
\hline $\begin{array}{l}-3 \mathrm{Mb} \\
-3.3 \mathrm{Mb}\end{array}$ & Hu4/Hu5 & $\begin{array}{l}21 f 12 \\
\text { (D4S180) }\end{array}$ & & $\begin{array}{l}\text { n.d. } \\
\text { n.d. }\end{array}$ & $\begin{array}{l}\text { n.d. } \\
\text { n.d. }\end{array}$ & $\begin{array}{l}\text { n.i. } \\
\text { n.d. }\end{array}$ & del & & & $\begin{array}{l}P \\
\text { del }\end{array}$ & & $\begin{array}{l}P \\
\text { del }\end{array}$ & $P$ & & M & n.i. \\
\hline $\begin{array}{l}-3.8 \mathrm{Mb} \\
-3.8 \mathrm{Mb}\end{array}$ & A2AR & $\begin{array}{l}\text { 228a7 } \\
\text { (D4S81) }\end{array}$ & & $\begin{array}{l}\text { n.i. } \\
\text { n.d. }\end{array}$ & $\begin{array}{l}\text { n.i. } \\
\text { n.d. }\end{array}$ & n.d. & del & del & del & $\begin{array}{l}\text { n.i. } \\
\text { del }\end{array}$ & del & $\begin{array}{l}P \\
\text { del }\end{array}$ & $\begin{array}{l}\text { n.i. } \\
\text { del }\end{array}$ & del & $\begin{array}{l}\text { n.i. } \\
\text { del }\end{array}$ & $\begin{array}{l}\text { n.i } \\
\text { del }\end{array}$ \\
\hline $\begin{array}{l}-5.5 \mathrm{Mb} \\
-5.5 \mathrm{Mb} \\
-7 \mathrm{Mb}\end{array}$ & Hox 7 & & $\begin{array}{l}424 \mathrm{H} 7 \\
877 \mathrm{G} 6\end{array}$ & & & & n.d. & $\begin{array}{l}\text { del } \\
\text { del }\end{array}$ & del & $\begin{array}{l}\text { n.i. } \\
\text { del }\end{array}$ & & $P$ & n.i & n.i & $\begin{array}{l}\text { n.i. } \\
\text { del }\end{array}$ & n.i. \\
\hline $\begin{array}{l}-8.8 \mathrm{Mb} \\
-9 \mathrm{Mb} \\
-10.6 \mathrm{Mb} \\
-13.0 \mathrm{Mb} \\
-14 \mathrm{Mb}\end{array}$ & D4S2366 & & $\begin{array}{l}\text { 911D6 } \\
392 C 3 \\
\text { 405D10 } \\
\text { 794D12 }\end{array}$ & n.d. & n.d. & n.d. & n.d. & $\begin{array}{l}\text { M } \\
\text { del } \\
\text { n.d. } \\
\text { n.d. } \\
\text { n.d. }\end{array}$ & $\begin{array}{l}\text { del } \\
\text { del } \\
\text { n.d. } \\
\text { n.d. }\end{array}$ & $\begin{array}{l}\text { P } \\
\text { del } \\
\text { del } \\
\text { n.d. } \\
\text { n.d. }\end{array}$ & $\begin{array}{l}\text { del } \\
\text { del } \\
\text { del } \\
\text { del }\end{array}$ & $P$ & $P$ & $P$ & del & n.i. \\
\hline $\begin{array}{l}-16.5 \mathrm{Mb} \\
-19.8 \mathrm{Mb} \\
-21.5 \mathrm{Mb}\end{array}$ & D4S403 & & $\begin{array}{l}\text { 225D2 } \\
435 \mathrm{~A} 11\end{array}$ & n.d. & & & n.i. & n.d. & n.d. & $\begin{array}{l}\text { n.d. } \\
\text { n.d. }\end{array}$ & n.d. & $\begin{array}{l}\text { P } \\
\text { n.d. }\end{array}$ & $\begin{array}{l}\text { P } \\
\text { del } \\
\text { del }\end{array}$ & $\begin{array}{l}\text { del } \\
\text { del }\end{array}$ & $\begin{array}{l}\text { n.i. } \\
\text { del }\end{array}$ & $P$ \\
\hline
\end{tabular}

del: deleted; n.d.: not deleted; n.i.: not informative; M: maternally deleted; P: paternally deleted.

non-specific hybridisation. Hybridisation was detected using monoclonal anti-digoxin, anti-mouse IgG FITC conjugate and anti-rabbit IgG FITC conjugate (Sigma Immuno Chemicals, St Louis, USA), and counterstained using propidiumiodide or DAPI. A cosmid derived from D4S96 and the whole chromosome paint 4 (AGS, Heidel berg, Germany/Oncor, Gaithersburg, VA, USA) were hybridised according to the manufacturer's instructions. For all hybridisations, clone pGXba11/340 25 was used as centromeric control for human chromosome4. The results of FISH analysis are listed in Table3. For patients 6 and 8, DNA of the parents was not available, so only FISH was used to determine the size of the deletion.

FISH staining with a whole chromosome paint 4 (AGS/ Oncor) gave hybridisation signals along the entire length of both chromosomes 4 in all 13 patients. Therefore, unbalanced translocations within the detection limit of wcp 4 were excluded in this group of patients. Smaller de novo translocations involving the short arm of one chromosome4 could not be excluded with this technique. Cryptic translocations in the parents were excluded performing FISH with at least one cosmid (D4S96 or CD2) in combination with clone pGXbal1/340 as control.

\section{Cell lines, genomic DNA isolation, and DNA probe analysis of the patients and their parents}

Genomic DNA was prepared from peripheral blood lymphocytes or EBV transformed lymphoblastoid cell lines from patients and their parents according to previously described techniques. $^{26,27}$

Genotyping of chromosome $4 p$ was performed using the following previously described microsatellite markers: D4S1182, ${ }^{28}$ D4S43, ${ }^{28}$ ADRA2C, ${ }^{21}$ HOX7, ${ }^{29,30}$ D4S403, ${ }^{31}$ D4S2366, D4S2639 and D4S2397. A new microsatellite, 75B9Rep, was generated by us and is described el sewhere. ${ }^{32,15}$ The Hu4/Hu5 primer pair amplifies the CAG repeat of the Huntington gene. $^{33,34}$ In patients 1,5 and 12 the maternal allele was absent, in contrast to patients $2,3,4,7,9,10,11$, 
and 13 , where the paternal allele was missing. The smallest deletion in this group of patients comprises $2.2-2.8 \mathrm{Mb}$ in patients 1 and 2, the largest deletion nearly $30 \mathrm{Mb}$ in patient 13. None of our patients had an interstitial deletion.

\section{Statistical evaluation}

For statistical analysis, Spearman correlation coefficient and the Fisher test were applied. A level of confidence of $\delta=0.05$ was used to assume a statistically significant difference.

\section{Results}

We compared the clinical findings in this group of WHS patients with the size of the deletion. The characteristic facial phenotype is present in all patients, reflecting that the suggested diagnosis was due to the facial gestalt. Cleft lip/ palate is present only in $3 / 13$ patients $(23.1 \%)$ and absent in patients with a terminal deletion smaller than $9 \mathrm{Mb}$. Preauricular pits/tags are reported in our patients in the same frequency as cleft lip/palate and are only present in patients with deletions larger than $10 \mathrm{Mb}$.

The standard deviations of birth weight and birth length correlate with the size of the deletion $(P<0.05)$, whereas head circumference at birth does not correlate. Interestingly, head circumference in older patients correlates with the size of the deletion $(P<0.05)$. The number of patients who learned to sit, walk and talk is too small to perform statistical analysis. However, it appears to us that patients with smaller deletions probably have a better developmental outcome than patients with large deletions. Patients 1,3 , and 4 are able to sit, walk and speak individual words; patient 2 was too young for us to assess these abilities. Patients 12 and 13 with the largest deletions at the age of 8 and 10 years, respectively, are neither able to sit or to communicate. Muscular hypotonia and seizures are present in nearly all patients independent of the size of the deletion. Deafness is present in three patients independent of the size of the deletion. Formal hearing testing has not been performed. Congenital heart defects were present in four patients $(30.7 \%)$ with size of the deletion ranging from nearly 16 to $29 \mathrm{Mb}$. However, in the patient with the largest deletion (patient 13), no heart defect has been recognised. Genital and renal anomalies are present in patients with small and large deletions. Colobomata of iris are lacking in patients with deletions smaller than $10 \mathrm{Mb}$.

The origin of deletion could be defined in 11 patients; $3 / 11$ patients had a deletion of maternal origin, whereas in $8 / 11$ patients the deletion was of paternal origin. It is noteworthy that all female WHS patients with known parental origin of deletion ( $n=6$ ) have deletion of paternal origin, whereas in 3/4 male WHS patients the deletion was of maternal origin. This result is statistically significant $(P<0.05)$. We could not identify statistically significant differences between the eight female and five male patients in respect of body measurements, clinical findings, or size of deletion.

\section{Discussion}

The Wolf-Hirschhorn syndrome (WHS) is a well known multiple congenital anomaly/mental retardation syndrome due to the partial deletion of the short arm of chromosome 4 involving at least a $165 \mathrm{~kb}$ segment of $4 \mathrm{p} 16.3 .^{6}$ Interstitial deletions of $4 p$ proximal to $4 p 16$, cause a phenotype distinct from WHS. ${ }^{35-37}$

Different mechanisms cause the deletion responsible in WHS: de novo simple deletions, unbalanced translocations due to familial translocations, or de novo complex chromosomal rearrangements such as unbalanced translocations result in $4 p$ deletions. Centerwall et $a^{38}$ estimated the frequency of unbalanced translocations in WHS to be $5 \%$; Lurie et al ${ }^{10}$ reviewed the literature and showed that $13 \%$ of the reported cases with WHS were caused by parental chromosomal aberrations. They concluded that the genetic structure of $4 p-$ does not differ from that of other autosomal deletion syndromes. Thus, of 22 cases of WHS we identified three (13.6\%) caused by familial translocations, which is consistent with the data from the literature. Six of 22 patients had a de novo unbalanced translocation, five of them with a de novo translocation $\mathrm{t}(4 \mathrm{p} ; 8 \mathrm{p}){ }^{15}$ In the remaining 13 patients described here in more detail, de novo deletions were detected.

The size of the terminal deletions in our patients ranged from nearly $2.5 \mathrm{Mb}$ to $31 \mathrm{Mb}$. The smallest deletion is submicroscopic at a banding resolution of 400 bands per haploid genome, the largest having a breakpoint in 4p15.2. This variability of cytogenetic visible deletions is well known. ${ }^{39}$

The frequency of clinical findings and mean body measurements in comparison with data in the literature are listed in Table3. We could not identify a statistically significant difference between males and females on the one hand and paternally and maternally inherited deletions on the other. Female liveborn WHS patients are more frequent than males, which has been documented in all reviews. An average 39 weeks gestation at birth in our group of patients agrees with the data of Wilson et al. $^{3}$ Birth weight ranged from $1580 \mathrm{~g}$ (patient 3 ) to $2750 \mathrm{~g}$ (patient 4) in our patients consistent with all reviews estimating an average birth weight of $2000 \mathrm{~g}$ (Table 2). Head circumference at birth is microcephalic with $31 \mathrm{~cm}$ in most of our WHS patients and in those described in the literature. Postnatal short stature is reported with a frequency of $76 \%$ to $100 \%$ and postnatal microcephaly is present in almost all reported patients. Estabrooks et $\mathrm{al}^{4}$ estimated the frequency of microcephaly to be lower (64\%). This might be due to the fact that they described WHS patients with small deletions. Mental retardation in patients in the literature was reported in more than $83 \%$. Unfortunately, no data about the mental devel opment of the patients with small deletions are included in some recent reports. Cleft lip and palate were more frequently observed in older reviews, ${ }^{40,41}$ this may be due to larger deletions in those patients. The same may be true for congenital heart 
Table 3 Frequency of clinical findings in our WHS patients compared with data in the literature

\begin{tabular}{|c|c|c|c|c|c|c|c|c|}
\hline & $\begin{array}{l}\text { Johnson } \\
\text { et } \mathrm{al}^{40} \\
\mathrm{n}=43 \\
\text { (review) }\end{array}$ & $\begin{array}{l}\text { Rivas } \\
\text { et al }^{41} \\
\mathrm{n}=37 \\
\text { (review) }\end{array}$ & $\begin{array}{l}\text { Wilson } \\
\text { et } \mathrm{al}^{3} \\
n=13\end{array}$ & $\begin{array}{l}\text { De } \\
\text { Grouchy }{ }^{53}\end{array}$ & Schinzel $\left.\right|^{54}$ & $\begin{array}{l}\text { Estabrooks } \\
\text { et } \mathrm{al}^{4} \\
\mathrm{n}=11\end{array}$ & $\begin{array}{l}\text { Battaglia } \\
\text { et } \mathrm{al}^{5} \\
\mathrm{n}=15\end{array}$ & $\begin{array}{l}\text { Our } \\
\text { data } \\
n=13\end{array}$ \\
\hline Sex & n.r. & $21 f / 16 m$ & $8 f / 5 m$ & $\begin{array}{l}\mathrm{f} / \mathrm{m}: \\
2 / 1 \text { ratio }\end{array}$ & $\begin{array}{l}\mathrm{f} / \mathrm{m}: \\
2 / 1 \text { ratio }\end{array}$ & $6 f / 5 m$ & $12 \mathrm{f} / 3 \mathrm{~m}$ & $8 f / 5 m$ \\
\hline \multicolumn{9}{|l|}{ Characteristic facial findings } \\
\hline Hypertelorism & $74 \%$ & $88 \%$ & $100 \%$ & n.r. & n.r. & $64 \%$ & $100 \%$ & $100 \%$ \\
\hline Prominent glabella & $47 \%$ & $50 \%$ & $92 \%$ & n.r. & n.r. & $55 \%$ & n.r. & $62 \%$ \\
\hline Broad nose & $64 \%$ & n.r. & $100 \%$ & n.r. & n.r. & $64 \%$ & n.r. & $100 \%$ \\
\hline Beaked nose & $64 \%$ & n.r. & n.r. & n.r. & n.r. & $55 \%$ & n.r. & $62 \%$ \\
\hline Short philtrum & n.r. & n.r. & n.r. & n.r. & n.r. & n.r. & $100 \%$ & $100 \%$ \\
\hline Micrognathia & $69 \%$ & $73 \%$ & $100 \%$ & n.r. & n.r. & $45 \%$ & $100 \%$ & $100 \%$ \\
\hline Downturned corners of the mouth & n.r. & n.r. & $100 \%$ & n.r. & n.r. & $45 \%$ & $100 \%$ & $77 \%$ \\
\hline Cleft lip/palate & $57 \%$ & $85 \%^{\mathrm{a}}$ & $31 \%$ & n.r. & $15 \%$ & $27 \%$ & $46.6 \%$ & $23 \%$ \\
\hline Dysplastic ears & $69 \%$ & $43 \%$ & $92 \%$ & n.r. & n.r. & $55 \%$ & $93.3 \%$ & $92 \%$ \\
\hline Preauricular tag/pit & n.r. & n.r. & $84 \%$ & n.r. & $>20 \%$ & $9 \%$ & n.r. & $23 \%$ \\
\hline Gestational weeks at birth (mean) & n.r. & n.r. & 39 & n.r. & n.r. & n.r. & & 39 \\
\hline $\begin{array}{l}\text { Birth weight in g (mean) } \\
\text { [SD] (mean) }\end{array}$ & n.r. & $<2000$ & 1870 & 2000 & 2000 & n.r. & n.r. & $\begin{array}{r}2241 \\
2.6\end{array}$ \\
\hline $\begin{array}{l}\text { Birth length in cm (mean) } \\
\text { [SD] (mean) }\end{array}$ & n.r. & n.r. & n.r. & 44 & n.r. & n.r. & n.r. & $\begin{array}{l}46.7 \\
-1.8\end{array}$ \\
\hline $\begin{array}{l}\text { OFC at birth in cm (mean) } \\
\text { [SD] (mean) }\end{array}$ & n.r. & n.r. & n.r. & 30.7 & 31 & n.r. & n.r. & $\begin{array}{l}31.2 \\
-3.2\end{array}$ \\
\hline Postnatal short stature & $76 \%$ & n.r. & $100 \%$ & n.r. & n.r. & $64 \%$ & $100 \%$ & $83 \%$ \\
\hline Postnatal stature in [SD] (mean) & n.r. & n.r. & n.r. & n.r. & n.r. & n.r. & n.r. & -3.8 \\
\hline Postnatal microcephaly & $91 \%$ & $90 \%$ & $100 \%$ & n.r. & n.r. & $64 \%$ & $100 \%$ & $100 \%$ \\
\hline Postnatal OFC in [SD] (mean) & n.r. & n.r. & n.r. & n.r. & n.r. & n.r. & n.r. & -4.1 \\
\hline Mental retardation & $100 \%$ & $83 \%$ & $100 \%$ & n.r. & n.r. & $91 \%$ & $100 \%$ & $100 \%$ \\
\hline Sitting without support & n.r. & n.r. & n.r. & n.r. & n.r. & n.r. & n.r. & $46 \%$ \\
\hline Walking without support & n.r. & n.r. & n.r. & n.r. & n.r. & n.r. & $26.7 \%$ & $31 \%$ \\
\hline Speech & n.r. & n.r. & n.r. & n.r. & n.r. & n.r. & n.r. & $23 \%$ \\
\hline Muscular hypotonia & n.r. & $60 \%$ & $100 \%$ & n.r. & n.r. & $64 \%$ & $93.3 \%$ & $92 \%$ \\
\hline Seizures & $47 \%$ & $53 \%$ & $92 \%$ & n.r. & n.r. & $55 \%$ & $86.6 \%$ & $85 \%$ \\
\hline \multicolumn{9}{|l|}{ Clinical findings } \\
\hline Coloboma & n.r. & $28 \%$ & $15 \%$ & n.r. & n.r. & n.r. & n.r. & $33 \%$ \\
\hline Strabism & $36 \%$ & $55 \%$ & $83 \%$ & n.r. & n.r. & $27 \%$ & n.r. & $62 \%$ \\
\hline Deafness & n.r. & n.r. & n.r. & n.r. & n.r. & $9 \%$ & $33.3 \%$ & $23 \%$ \\
\hline Congenital heart defect & $55 \%$ & $60 \%$ & $23 \%$ & $>50 \%$ & n.r. & $18 \%$ & $33.3 \%$ & $31 \%$ \\
\hline Clubbing of fingers/toes & n.r. & n.r. & $77 \%$ & n.r. & n.r. & $45 \%$ & n.r. & $46 \%$ \\
\hline Scoliosis & $66 \%$ & n.r. & $23 \%$ & n.r. & n.r. & $18 \%$ & $13.3 \%$ & $15 \%$ \\
\hline Club feet & n.r. & $63 \%$ & $53 \%$ & n.r. & n.r. & $18 \%$ & n.r. & $15 \%$ \\
\hline Renal anomalies & n.r. & n.r. & n.r. & n.r. & n.r. & $18 \%$ & $13.3 \%$ & $23 \%$ \\
\hline Genital anomalies & $64 \%$ & n.r. & $80 \%$ & n.r. & n.r. & $36 \%$ & n.r. & $31 \%$ \\
\hline Sacral dimple & $33 \%$ & $35 \%$ & $100 \%$ & n.r. & n.r. & $27 \%$ & n.r. & $8.3 \%$ \\
\hline
\end{tabular}

f: female; m: male; n.r.: not reported; aincluding all palatal anomalies, not only cleft lip/palate.

defects. ${ }^{40,41}$ However, in more recent papers, where the deletions have been characterised with molecular methods, clinical data were not described in detail and photographs were lacking, which adds to a controversial debate if the variability of the clinical spectrum seen in WHS is reflected by the size of the deletion. ${ }^{6,42}$

We correlated the clinical findings with the size of the deletion and came to the following conclusions: cleft lip/ palate, preauricular pits/tags, and colobomata were missing in patients with deletions smaller than $9 \mathrm{Mb}$ and congenital heart defects were absent in patients with deletions smaller than $16 \mathrm{Mb}$. These conclusions are supported by other reported patients with small deletions, who lacked these clinical findings, eg the patients of Albiez et al, ${ }^{43}$ Gandelmann et $\mathrm{al}^{42}$ and Johnson et al. ${ }^{40}$ Johnson et al ${ }^{14}$ hypothesised that cardiac and lip and palatal defects are due to deletions located more proximally. Fang et $a^{44}$ added renal abnormalities and hearing loss to this list.

Reduced length and height correlate with the size of the deletion, which is also true of head circumferences in older patients. To our knowledge in this respect, there are no detailed literature data for comparison. The number of patients who are able to walk or to talk is too small to argue whether the degree of developmental delay correlates with the size of the deletion, as suggested by Johnson et al. ${ }^{40}$ Estabrooks et $\mathrm{al}^{4,45}$ hypothesised that the size of the deletion 
and clinical severity do not correlate. This may be due to the fact that these authors included WHS patients only with small deletions. Moreover, they also concluded that severe mental retardation appears to be associated with more distal deletions, and mild mental retardation appears to be associated with a more proximal, interstitial $4 p 16$ deletion as by Fang et al. ${ }^{44}$

Estabrooks et $\mathrm{al}^{4}$ performed a preliminary phenotypic map of chromosome 4 p16 based on 11 WHS patients with deletions smaller than $8 \mathrm{Mb}$. Lurie and Opitz $^{46}$ question the attempt to map nonspecific findings common to many different forms of segmental autosomal aneuploidies to a specific region. Estabrooks et $\mathrm{al}^{4}$ also included patients with additional autosomal trisomic segments, which may have an influence on the phenotype. In concordance with their data, we agree that preauricular pits/tags and congenital heart defects are present only in patients with larger deletions. Hearing loss was present in one patient with a small deletion in our group of patients and is in contrast to this map. These authors ${ }^{4}$ suggest that seizures may be mapped to the distal region because they are present in nearly all patients. We do not agree with cleft lip/palate being localised distally as discussed above, because of the absence of this sign in our patients with small deletions.

In this paper we do not differentiate between patients with Pitt-Rogers-Danks and Wolf-Hirschhorn syndrome. These conditions are both caused by deletions in the same region on chromosome4p16.3. ${ }^{47}$ Clinical phenotype is so similar and may change in one person at different ages. Thus, we agree that these conditions are not distinct entities. ${ }^{48}$

In conclusion, the standard deviations of birth weight, birth length, and postnatal head circumference, and the severity of mental retardation correlate with the size of the deletion.

\section{Acknowledgements}

We thank Professor Eberhard Passarge for continuous support and reading the manuscript, and Professor Bernhard Horsthemke for helpful discussion. In addition, we thank Barbara Henke, Barbara Ulrich, Elke Jürgens, and Gudrun Rodepeter for excellent technical assistance, and the parents for taking part in this study. We thank $\mathrm{Dr}$ Herdit Schüler for the results of previous chromosomal analysis in patient 1, Dr AJH Hamers for performing FISH with D4S10 in patient 2, and Dr JJM Engelen for FISH in patient4. We also thank Tracy W right for the cosmids $\mathrm{pC} 847.351,33 \mathrm{c}, 21 \mathrm{f} 12$ and 228a7. In addition, we thank CEPH for providing the YACs. DW and GG-K were supported in part by a young investigators' grant from the Medical Faculty, University of Essen (IFORES107402.0), and by the Deutsche Forschungsgemeinschaft (W i 1440/4-1).

\section{References}

1 Wolf U, Reinwein H, Porsch R, Schröter R, Baitsch H: Defizienz an den kurzen Armen eines Chromosoms Nr 4. Humangenetik 1965; 1: 397-413.

2 Hirschhorn K, Cooper HL, Firschein IL: Deletion of short arms of chromosome 4-5 in a child with defects of midline fusion. Humangenetik 1965; 1: 479-482.
3 Wilson MG, Towner JW, Coffin GS, Ebbin AJ, Siris E, Brager P: Genetic and clinical studies in 13 patients with the WolfHirschhorn syndrome [del(4p)]. Hum Genet 1981; 59: 297-307.

4 Estabrooks LL, Rao KW, Driscoll DA et al: Preliminary phenotypic map of chromosome 4p16 based on 4p deletions. Am J Med Genet 1995; 57: 581-586.

5 Battaglia A, Carey JC, Cederholm P et al: Natural history of WolfHirschhorn syndrome: Experience with 15 cases. Pediatrics 1999; 103: 830-836.

6 Wright TJ, Ricke DO, Denison $\mathrm{K}$ et al: A transcript map of the newly defined $165 \mathrm{~kb}$ Wolf-Hirschhorn syndrome critical region. Hum Mol Genet 1997; 6: 317-324.

7 Stec I, Wright TJ, van Ommen G-JB et al: WHSC1, a $90 \mathrm{~kb}$ SET domain-containing gene, expressed in early development and homologous to a Drosophila dysmorphy gene maps in the WolfHirschhorn syndrome critical region and is fused to IgH in $\mathrm{t}(4 ; 14)$ multiple myeloma. Hum Mol Genet 1998; 7: 1071-1082.

8 Wright TJ, Costa JL, Naranjo C, Francis-West P, Altherr MR: Comparative analysis of a novel gene from the Wolf-Hirschhorn/ Pitt-Rogers-Danks syndrome critical region. Genomics 1999; 59: 203-212.

9 Endele S, Fuhry M, Pak S-J, Zabel B, Winterpacht A: LETM1 - a novel gene encoding a putative EF-hand $\mathrm{Ca} 2$ +-binding protein flanks the Wolf-Hirschhorn syndrome (WHS) critical region and is deleted in most WHS patients. Genomics 1999; 60(2): 218-225.

10 Lurie IW, Lazjuk GI, Ussova YI, Presman EB, Gurevich DB: The Wolf-Hirschhorn syndrome. I. Genetics. Clin Genet 1980; 17: 375-384.

11 Nahara K, Himoto $Y$, Yokoyama $Y$ et al: The critical monosomic segment in 4p- syndrome: a high-resolution banding study on five inherited cases. Jpn J Hum Genet 1984; 29: 403-413.

12 Quarrell OWJ, Snell RG, Curtis MA, Roberts SH, Harper PS, Shaw DJ: Paternal origin of the chromosomal deletion resulting in Wolf-Hirschhorn syndrome. J Med Genet 1991; 28: 256-259.

13 Tupler R, Bortotto L, Bühler EM et al: Paternal origin of the de novo deleted chromosome4 in Wolf-Hirschhorn syndrome. J Med Genet 1992; 29: 53-55.

14 Johnson VP, Altherr MR, Blake JM, Keppen LD: FISH detection of Wolf-Hirschhorn syndrome: Exclusion of D4F26 as critical site. Am J Med Genet 1994; 52: 70-74.

15 Wieczorek D, Krause M, Majewski $F$ et al: Unexpected high frequency of de novo unbalanced translocations in patients with Wolf-Hirschhorn syndrome (WHS). J Med Genet 2000 (in press).

16 Seabright $M$ : A rapid banding technique for human chromosomes. Lancet 1971; 2: 971-972.

17 Mitelman F (ed): ISCN. An International System for Human Cytoge netic Nomenclature. Karger: Basel, 1995.

18 Altherr MR, Smith B, MacDonald ME, Wasmuth J]: Isolation of a novel mildly repetitive DNA sequence that is predominantly located at the terminus of the short arm of chromosome 4 near the Huntington disease gene. Genomics 1989; 5: 581-588.

19 Whaley WL, Bates GP, Novelletto A et al: Mapping of cosmid clones in Huntington's disease region of chromosome4. Somat Cell Mol Genet 1991; 17: 83-91.

20 Riess O, Siedlaczck I, Kredtke S, Melmer G, Epplen JT, Deaven LL: Characterization of a human chromosome 4 flow-sorted cosmid library. Cytogenet Cell Genet 1994; 65: 238-242.

21 Riess O, Thies U, Siedlaczck I et al: Precise mapping of the brain 2 -adrenergic receptor gene within chromosome4p16. Genomics 1994; 19: 298-302.

22 Perez-Castro AV, Wilson J, Altherr MR: Genomic organization of the mouse fibroblast growth factor receptor 3 (FGFR3) gene. Genomics 1995; 30: 157-162.

23 Lengauer C, Green ED, Cremer T: Fluorescence in situ hybridization of YAC clones after Alu-PCR amplification. Genomics 1992; 13: 826-828.

24 Lichter $\mathrm{P}$, Chang $\mathrm{C}-\mathrm{J}$, Call $\mathrm{K}$ et al: High resolution mapping of human chromosome11 by in situ hybridization with cosmid clones. Science 1990; 247: 64-67. 
25 Hulsebos T, Schonk D, Schepens J et al: Isolation and characterization of repetitive al phoid sequences specific for the centromers of chromosomes 4 and 19. Cytogenet Cell Genet 1987; 46: 632.

26 Neitzel H: A routine method for the establishment of permanent growing lymphoblastoid cell lines. Hum Genet 1986; 73: 320-326.

27 Miller SA, Dykes DD, Plesky HF: A simple salting out procedure for extracting DNA from human nucleated cells. Nucleic Acids Res 1988; 6: 1215.

28 Goold RD, diSibio GL, Xu H et al: The development of sequencetagged sites for human chromosome4. Hum Mol Genet 1993; 2: 1271-1288.

29 Padanilam BJ, Stadler HS, Mills KA et al: Characterization of the human HOX 7 CDNA and identification of polymorphic markers. Hum Mol Genet 1992; 1: 407-410.

30 Cooperative Human Linkage Centre (CHLC): A comprehensive genetic linkage map with centimorgan density. Science 1994; 265: 2049-2054.

31 Gyapay G, Morissette J, Vignal A et al: The 1993-94 Généthon human genetic linkage map. Nat Genet 1994; 7: 246-339.

32 Baxendale $\mathrm{S}, \mathrm{MacD}$ onald ME, Mott $\mathrm{R}$ et al: $\mathrm{A}$ cosmid contig and high resolution restriction map of the 2 megabase region containing the Huntington's disease gene. Nat Genet 1993; 4: 181-186.

33 Riess O, Noerremoelle A, Soerensen SA, Epplen JT: Improved PCR conditions for the stretch of (CAG) $)_{n}$ repeats causing Huntington's disease. Hum Mol Genet 1993; 2: 637.

34 Rubinsztein DC, Barton DE, Davison BC, Ferguson-Smith MA: Analysis of the Huntington gene reveals a trinucleotide-length polymorphism in the region of the gene that contains two CCGrich stretches and a correlation between decreased age of onset of Huntington's disease and CAG repeat number. Hum Mol Genet 1993; 2: 1713-1715.

35 Francke U, Arias DE, Nyhan WL: Proximal 4p (-) deletion phenotype differs from classical $4 p(-)$ syndrome. Pediatrics 1977; 90: $250-252$.

36 Estabrooks LL, Rao KW, Korf B: Interstitital deletion of distal chromosome $4 p$ in a patient without classical Wolf-Hirschhorn syndrome. Am J Med Genet 1993; 45: 97-100.

37 Chitayat D, Ruvalcaba RHA, Babul R et al: Syndrome of proximal interstitial deletion 4p15: Report of three cases and review of the literature. Am J Med Genet 1995; 55: 147-154.

38 Centerwall WR, Thompson WP, Irving EA, Fobes CD: Translocation 4p- syndrome. Am J Dis Child 1975; 129: 366-370.
39 Schinzel A: Autosomale Chromosomenaberrationen. Arch Genet (Zur) 1979; 52: 1-204.

40 Johnson VP, Mulder RD, Hosen R: The Wolf-Hirschhorn (4p-) syndrome. Clin Genet 1976; 10: 104-112.

41 Rivas F, Hernandez A, Nazara Z et al: On the deletion 4p16 WolfHirschhorn syndrome. Ann Génét 1979; 22: 228-231.

42 Gandelmann K-Y, Gibson L, Meyn MS, Yang-Feng TL: Molecular definition of the smallest region of deletion overlap in the WolfHirschhorn syndrome. Am J Hum Genet 1992; 51: 571-578.

43 Albiez KL, Phelan MC, Stevenson RE: Wolf-Hirschhorn syndrome and a minute deletion of 4p16.3. Am J Hum Genet 1987; 41: Al12.

44 Fang Y-Y, Bain S, Haan EA et al: High resolution characterization of an interstitial deletion of less than $1.9 \mathrm{Mb}$ at $4 \mathrm{p} 16.3$ associated with Wolf-Hirschhorn syndrome. Am J Med Genet 1997; 71: 453-457.

45 Estabrooks LL, Lamb AN, Aylsworth AS, Callanan P, Rao KW: Molecular characterisation of chromosome $4 p$ deletions resulting in Wolf-Hirschhorn syndrome. J Med Genet 1994; 31: 103-107.

46 Lurie IW, Opitz JM: Phenotypic mapping and clinical ideology. Am J Med Genet 1995; 57: 587.

47 Kant SG, van Haeringen A, Bakker E et al: Pitt-Rogers-Danks syndrome and Wolf-Hirschhorn syndrome are caused by a deletion in the same region on chromosome4p16.3. J Med Genet 1997; 34: 569-572.

48 Battaglia A, Carey JC: Wolf-Hirschhorn syndrome and Pitt-RogersDanks syndrome. Am J Med Genet 1998; 75: 541.

49 Keen DV, Pearse RG: Weight, length, and head circumference curves for boys and girls of between 20 and 42 weeks' gestation. Arch Dis Child 1988; 63: 1170-1172

50 Van Wieringen JC, Wafelbakker F, Verbrugge HP, de Haas JH: Growth Diagrams 1965 Netherlands Second National Survey on 0-24-year-olds. Wolters-Noordhoff Publishing: Groningen, 1971, pp 1-68.

51 Kunze D: Perzentilkurven zur Bestimmung der Alters-/Größenund der Größen-/Gewichtsbeziehung. Der Kinderarzt 1977; 8: 979-986.

52 Nellhaus G: Head circumference from birth to eighteen years. Practical composite international and interracial graphs. Pediatrics 1968; 41: 106-114.

53 De Grouchy J, Turleau C: Clinical Atlas of Human Chromosomes. Wiley Medical: New York, Chichester, Brisbane, Toronto, Singapore, 1986.

54 Schinzel A: Catalogue of Unbalanced Chromosome Aberration in Man. de Gruyter: New York, 1984. 